J. Shadick, Mr. and Mrs. J. D. Hogg, Betty Long, Helen, Mann, F. Roy, R. Pravda, Dr. R Bremner, Mrs. M. Evans of Saskatoon; Mr. and Mrs. B. Knox, E. Good, W. Baker, Mr. and Mrs. L. McK. Robinson, Dr. Frances McGill, Mrs. J. C. Black, Mrs. R. Williams, Gertrude Murray, Thelma Brady, Mrs. M. Willers, Marguerite Robertson, F. G. Bard, B. C. Shier, B. McCorquodale, Joyce Dew, Helen Rempel, Frances McKay, Wolfram Niessen, Mr. and Mrs. R. W. Fyfe, Dr. and Mrs. R. W. Nero, Dr and Mrs. G. F. Ledingham, Mrs. E. Cruick- shank, Dr. Lucy Murray, Mrs. G Hodgins, Edna Colbeck, Kay Armstrong, Margaret Belcher, W. A Silverthorn, Mr. and Mrs. D. Gilroy cif. Regina.

OUTSIDE SASKATCHEWAN:

Mr. and Mrs. L. H. Stokes of Winnipeg; W. Crossley, Grandview, Man T. Dutton, Gilbert Plains, Man.; Mr and Mrs. E. Robinson, Wawanesa Man.; L. M. Lohr, Erskine, Alta. Kathleen Hodges, A. Hodges, Calgary D. H. Barnett, Toronto; Mr. and Mrs Herman F. Chapman, Sioux Falls S. D.; S. A. Stueck of Ventura, Cal

\title{
S.N.H.S. SUMMER MEETING AT EMMA LAKE
}

The Saskatchewan Natural History Society has been invited by the Prince Albert Natural History Society to hold its 1958 summer meeting at Emma Lake.We are pleased to accept the invitation of the P. A. society, and we suggest that you plan now to be at Emma Lake next summer.

\section{The BLUE JAY Bookshelf}

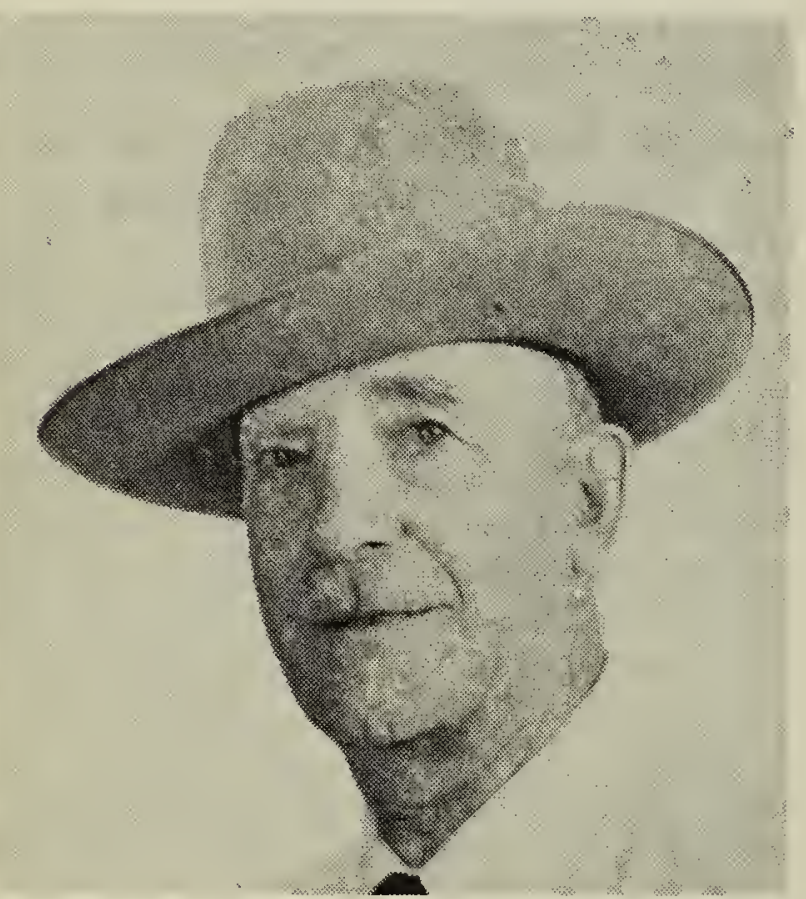

Wild Plants of the Canadian Prairies

By A. C. Budd. Publication No. 983, Canada Department of Agriculture, Ottawa, 1957. $\$ 1.50$.

This is a revision in more convenient format of the mimeographed publication "Wild Plants of the Farming and Ranching Areas of the Canadian Prairies," Ottawa, 1952. As such, it remains the only usable flora of the Canadian Prairies. Those of us who had to learn to recognize our plants 'from Rydberg's confusing and often misleading writings wlll know what a need it fills. It could be, even, that the author has not been quite ruthless enough in eliminating the Rydbergian phoney species I notice a few left in Aster, for example.
The keys seem eminently work. able. Some people have regretted the necessity for keys saying, "Wh: aren't there more pictures? Thi answer is that when over 1201 species are to be described there $\mathrm{i}$ : no escape from written keys. Thi author has taken pains, as he says, ti keep the language as simple anc non-technical as possible; but a cer. tain amount of work is yet requirer from those who would use this book The utter novice would be well ad. vised to begin by going over care fully the introductory material - th diagrams and descriptions of plan parts and the directions for using th keys. This explanatory text, on notes, has been enlarged and trans ferred to the front of the book in th new edition. Perhaps in the writtes text special mention might have bee made of some plants which are har to key out, e.g. a greenhorn coul have quite a time trying to decid if members of the Ragweed sub family have both calyx and coroll in the flowers.

The printing is clear and the lin drawings (by the author) have charming quality. There are 6 species shown in the drawings; the number should give the novice foothold from which to study furthe: A hard cover might have been use ful, considering the field usage man copies are destined for. - John $F$ Hudson, Regina. 